\title{
Relatively lower body mass index is associated with an excess of severe truncal asymmetry in healthy adolescents: Do white adipose tissue, leptin, hypothalamus and sympathetic nervous system influence truncal growth asymmetry?
}

\author{
Theodoros B Grivas*1,2, R Geoffrey Burwell ${ }^{3}$, Constantinos Mihas1, \\ Elias S Vasiliadis ${ }^{1}$, Georgios Triantafyllopoulos ${ }^{1}$ and Angelos Kaspiris ${ }^{1}$
}

\begin{abstract}
Email: Theodoros B Grivas* - grivastb@vodafone.net.gr; R Geoffrey Burwell - gburwell@tiscali.co.uk; Constantinos Mihas - gas521@yahoo.co.uk; Elias S Vasiliadis - eliasvasiliadis@yahoo.gr;

Georgios Triantafyllopoulos - geotriantas@ath.forthnet.gr; Angelos Kaspiris - angkaspiris@upatras.gr

* Corresponding author
\end{abstract}

Address: ${ }^{1}$ Department of Trauma and Orthopaedics, Scoliosis Clinic, "Thriasio" General Hospital - NHS, G. Gennimata Av. 19600, Magoula Attica, Greece, ${ }^{2}$ Department of Trauma and Orthopaedics, "Tzanio" General Hospital - NHS, Tzani \& Afendouli str, 18536, Piraeus, Greece and ${ }^{3}$ Centre for Spinal Studies \& Surgery, Nottingham University Hospitals Trust, Queen's Medical Centre Campus, Nottingham NG7 2UH, UK

Published: 30 June 2009

Scoliosis 2009, 4:13 doi:10.1186/1748-7/6I-4-13

This article is available from: http://www.scoliosisjournal.com/content/4/I/I3

(C) 2009 Grivas et al; licensee BioMed Central Ltd.

This is an Open Access article distributed under the terms of the Creative Commons Attribution License (http://creativecommons.org/licenses/by/2.0), which permits unrestricted use, distribution, and reproduction in any medium, provided the original work is properly cited.
Received: 13 December 2008

Accepted: 30 June 2009

\begin{abstract}
Background: In healthy adolescents normal back shape asymmetry, here termed truncal asymmetry (TA), is evaluated by higher and lower subsets of BMI. The study was initiated after research on girls with adolescent idiopathic scoliosis (AIS) showed that higher and lower BMI subsets discriminated patterns of skeletal maturation and asymmetry unexplained by existing theories of pathogenesis leading to a new interpretation which has therapeutic implications (double neuro-osseous theory).
\end{abstract}

Methods: 5953 adolescents age II-I7 years (boys 2939, girls 30I4) were examined in a school screening program in two standard positions, standing forward bending (FB) and sitting FB. The sitting FB position is thought to reveal intrinsic TA free from back humps induced by any leg-length inequality. TA was measured in both positions using a Pruijs scoliometer as angle of trunk inclinations (ATIs) across the back at each of three spinal regions, thoracic, thoracolumbar and lumbar. Abnormality of ATIs was defined as being outside 2 standard deviations for each age group, gender, position and spinal region, and termed severe TA.

Results: In the sitting FB position after correcting for age,relatively lower BM/s are statistically associated with a greater number of severe TAs than with relatively higher BMls in both girls (thoracolumbar region) and boys (thoracolumbar and lumbar regions).

The relative frequency of severe TAs is significantly higher in girls than boys for each of the right thoracic $(56.76 \%)$ and thoracolumbar $(58.82 \%)$ regions $(p=0.006,0.006$, respectively). After correcting for age, smaller BMls are associated with more severe TAs in boys and girls.

Discussion: BMI is a surrogate measure for body fat and circulating leptin levels. The finding that girls with relatively lower BMI have significantly later menarche, and a significant excess of TAs, suggests a relation to energy homeostasis through the hypothalamus. The hypothesis we suggest 
for the pathogenesis of severe TA in girls and boys has the same mechanism as that proposed recently for AIS girls, namely: severe TAs are initiated by a genetically-determined selectively increased hypothalamic sensitivity (up-regulation, i.e. increased sensitivity) to leptin with asymmetry as an adverse response to stress (hormesis), mediated bilaterally mainly to the growing trunk via the sympathetic nervous system (leptin-hypothalamic-sympathetic nervous system (LHS) concept). The putative autonomic dysfunction is thought to be increased by any lower circulating leptin levels associated with relatively lower BMls. Sympathetic nervous system activation with asymmetry leads to asymmetries in ribs and/or vertebrae producing severe TA when beyond the capacity of postural mechanisms of the somatic nervous system to control the shape distortion of the trunk. A test of this hypothesis testing skin sympathetic responses, as in the Rett syndrome, is suggested.

\section{Introduction}

The value of school screening for scoliosis has largely been an appreciation of the high prevalence of small degrees of surface deformity and curvature and the opportunity to study the natural history of these curvatures $[1,2]$. Not adequately recognised is the potential, through epidemiological studies of screened subjects, to understand better some factors involved in the pathogenesis of adolescent idiopathic scoliosis (AIS) [3-13]. In this connection, body mass index (BMI) has been evaluated in relation to both AIS [14-23] and the trunk asymmetry (TA) of normal subjects $[7,16,23-25]$. But no attempts have been made to evaluate how BMI may relate to the pathogenesis of the trunk shape distortion of TA as it has recently for girls with AIS [23].

Employing a new approach of comparing skeletal data between subsets of higher and lower body mass index (BMI) in adolescent girls - preoperative with AIS, screened for AIS and normals, BMI was found to be related to skeletal maturation of the trunk, and to some skeletal asymmetries of AIS [23]. The findings were not explained by any of the theories of pathogenesis for AIS surveyed in a recent review [26]. A novel pathogenetic interpretation was formulated as a double neuro-osseous theory, involving disharmony between the autonomic and somatic nervous systems expressed in the spine and trunk with therapeutic implications [27-30].

In normal adolescents, we test whether such BMI subsets are related to severe TAs. To prepare our TA data for analysis, the known compounding factor of any leg-length inequality on back shape was removed. This was done by basing the interpretation on TA readings obtained from subjects in the sitting FB position, because when a healthy child is examined in the standing FB position, shortness of one leg causes a contralateral hump on the back [31-40]. Previous research suggested that the sitting FB position expresses intrinsic TAs free from extrinsically-induced effects of any leg-length inequality [34,41-43].

Normal TAs and AIS form a continuum of TAs with thresholds needed to prescribe abnormality $[1,2,37,42]$.
In a 3-year longitudinal study of TA in healthy prepubertal school children, scoliosis curves of 10 degrees or more occurred in $9.5 \%$ of girls and $5.1 \%$ of boys [24]. The biological mechanisms that cause TA are ill-understood but are likely to have some common ground with the pathogenesis of AIS, where genetic factors and the fully upright human spine may play decisive roles [44]. In premenarcheal girls, left truncal humps $[41,42,45]$ and left scoliosis curves [6] are more prevalent than are right humps, or curves. In postmenarcheal girls, right humps become prevalent.

Skeletal imaging studies have examined TAs in relation to:

- rib-vertebra angle asymmetry [46,47];

- convex/concave rib-hump index ('double rib contour sign') $[9,48]$;

- vertebral sagittal profile $[26,49,50]$; and

- ultrasound axial vertebral and rib rotations [51] viewed in relation to radiographic axial vertebral rotation [26,51-53] and spine-rib rotation difference [54].

Changes in TA with age in normal subjects leading to AIS have been interpreted as resulting from growth with the rib cage deformity preceding the spinal deformity [48].

The aims of this paper in normal girls and boys are firstly, to examine the relationship between (1) severe trunk asymmetry, (2) menarche and (3) two BMI subsets - relatively higher and lower than median values for age, sex, and spinal region and secondly, to interpret the findings from the standpoint of TA pathogenesis. A preliminary report has been presented [55].

\section{Methods}

\section{The healthy children}

Throughout the school period (September to June) from 1996 to $2007,5,953$ children (2939 boys with a mean age $13.39 \pm 1.48$ and 3014 girls with a mean age $13.39 \pm 1.48$ 
years), were examined during the school screening program of the hospital (Table 1).

\section{Examination and measurements (Figures I \&2)}

TA was measured in two standard positions, standing FB and sitting FB. TA was assessed using a Pruijs Scoliometer (Orthomet-Surgeyplant B.V. Waalwijl, Netherlands) [56]) by measuring angles of trunk inclination (ATIs) in degrees at each of thoracic (T4-T8), thoracolumbar (T12-L1) and lumbar (L2-5) regions of the back. The child was asked to bend forwards, look down, keeping the feet $15 \mathrm{~cm}$ apart, knees braced back, shoulders loose, and hands positioned in front of the knees or shins with elbows straight and palms apposed (Figure 1). Any detected leg-length inequality was not corrected. The side of the hump determined the laterality of the trunk inclination, humps on the right (positive) and on the left (negative) in each of the three spinal regions. In the sitting FB position (Figure 2 ), the student was seated on a chair about $40 \mathrm{~cm}$ high, and asked to bend forwards and place the head between the knees with shoulders loose, elbows straight and hands positioned between the knees. The scoliometer measurements were obtained successively at the three spinal regions as in the standing FB position. The reproducibility of the scoliometer measurements has been reported [8].

\section{Stature}

The standing height was measured using a stature meter in $\mathrm{cm}$.

Table I: Age distribution of the examined children by gender. Gender frequency does not change among age groups, (chisquare for trend $\mathrm{p}=\mathbf{0 . 8 8 0}$ )*.

\begin{tabular}{|c|c|c|c|c|c|c|}
\hline & & \multicolumn{4}{|c|}{ Gender } & \multirow{3}{*}{ Coun } \\
\hline & & \multicolumn{2}{|c|}{ Boys } & \multicolumn{2}{|c|}{ Girls } & \\
\hline & & Count & Row \% & Count & Row \% & \\
\hline \multirow{7}{*}{$\begin{array}{l}\text { Decimal Age } \\
\text { categories }\end{array}$} & 11 & 595 & $49.5 \%$ & 608 & $50.5 \%$ & 1203 \\
\hline & 12 & 678 & $49.7 \%$ & 686 & $50.3 \%$ & 1364 \\
\hline & 13 & 677 & $47.6 \%$ & 745 & $52.4 \%$ & 1422 \\
\hline & 14 & 586 & $50.6 \%$ & 571 & $49.4 \%$ & 1157 \\
\hline & 15 & 239 & $52.8 \%$ & 214 & $47.2 \%$ & 453 \\
\hline & 16 & 112 & $46.7 \%$ & 128 & $53.3 \%$ & 240 \\
\hline & 17 & 52 & $45.6 \%$ & 62 & $54.4 \%$ & 114 \\
\hline Total & & 2939 & $49.4 \%$ & 3014 & $50.6 \%$ & 5953 \\
\hline
\end{tabular}

* There are missing values of some variables so the same numbers (absolute frequencies) are not the same in all Tables.

\section{Weight}

Body weight was assessed using a weight scale with $0.5 \mathrm{~kg}$ increments.

\section{Body mass index (BMI)}

BMI was calculated as body weight in $\mathrm{kg} /$ stature in meters².

\section{Stature SD scores}

Stature SD scores (SDSs), or Z scores, were calculated as the difference between the observed $(y)$ and the mean value $(\mathrm{Y})$ for age divided by the standard deviation (SD) of the mean for each age year and sex. SDS (SDS = Z score) $=(\mathrm{y}-\mathrm{Y}) / \mathrm{SD}$

\section{Grouping of ATIs}

First method - by absolute numbers

At each of the three spinal regions on the child's back in each of the standing and sitting FB positions, group 0 consisted of children who were symmetric; group 1 children with ATIs $1-6^{\circ}$; and group 2 the ATI was $7^{\circ}$ or more [16].

\section{Second method - outside 2 standard deviations}

Children were categorized in two groups: Group a) mean ATI \pm 2 standard deviations (SDs), and group b) ATIs higher or lower than the aforementioned value range termed here outside or beyond 2 SDs $(>$ or $<$ ), or severe TA. The last group was also transformed by laterality into two subgroups each beyond 2 SDs, group brt and group $b l$, with TA right and left respectively.

\section{Grouping of BMI - above and below median values}

A BMI median value was constructed for each age group, gender, position and spinal region, and each child assigned a value of relatively "lower" or relatively "higher" $B M I$ subset in relation to the median values.

\section{Menarcheal age and BMI}

The mean age at which girls had their menarche was calculated for both higher and lower BMI subgroups as were the numbers of pre- and post-menarcheal girls. Other assessments of sexual maturity are not available for the girls. Sexual maturity findings were not obtained from the boys.

\section{Statistical analysis \& data processing}

The scoliometer ATI readings were analysed by spinal region, sex, side, age and BMI subset.

In order to test for any independence between categorical variables, tables were constructed and the Pearson Chisquared test was used.

Continuous variables are shown as means and standard deviations (SDs). 


\section{Boys and girls 11-17 years Standing forward bending position ATIs outside 2 SDs by sex, site and side}
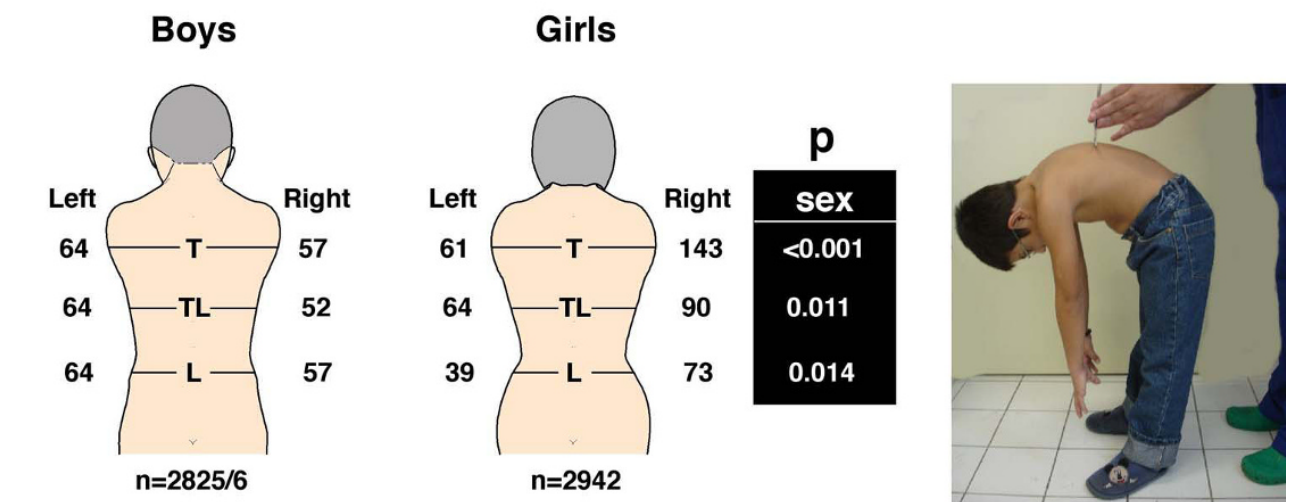

$\mathrm{T}=$ thoracic $\mathrm{TL}=$ Thoracolumbar $\mathrm{L}=\mathrm{Lumbar}$

Figure I

Boys and girls I I-I7 years. Standing forward bending position. Angle of trunk inclinations (ATIs), number outside \pm 2 standard deviations by sex, site and side. Note the difference of the number of severe TAs between boys and girls with $P$ values by region.

\section{Boys and girls 11-17 years Sitting forward bending position ATIs outside 2 SDs by sex, site and side}

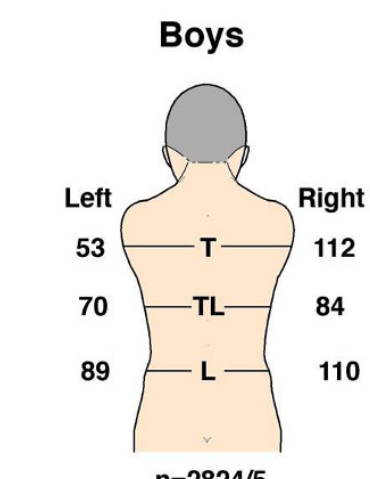

$n=2824 / 5$
Girls
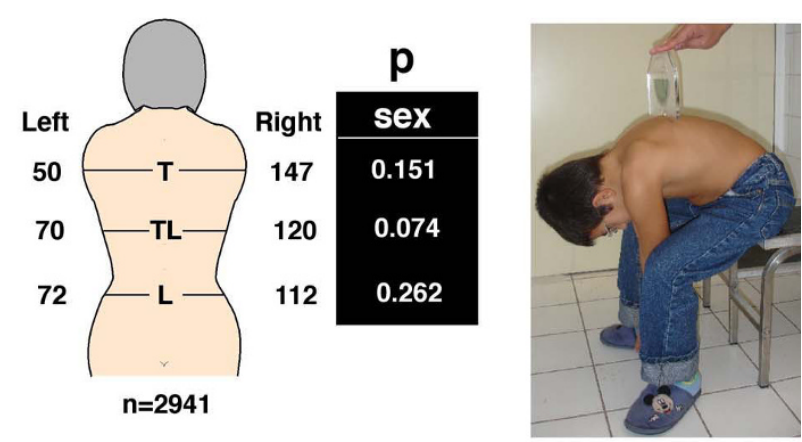

\section{$\mathrm{T}=$ thoracic $\mathrm{TL}=$ Thoracolumbar $\mathrm{L}=\mathrm{Lumbar}$}

Figure 2

Boys and girls I I-I 7 years. Sitting forward bending position. Angle of trunk inclinations (ATls), number outside \pm 2 standard deviations by sex, site and side. Note there is no difference of the number of severe TAs between boys and girls with $P$ values by region. But for the right thoracic region, the relative frequency of severe TAs is significantly higher in girls than boys (respectively $5.08 \%$ and $4.04 \%, p=0.006$ ) and right thoracolumbar region (respectively $4.18 \%$ and $4.04 \%, p=0.023$ ). 
Stature SDSs were plotted versus ATIs for each gender and spinal region (thoracic, thoracolumbar, lumbar) in both standing and sitting FB positions in order to investigate any association between TA and age with the Pearson's correlation coefficients being calculated.

The corresponding univariate linear regression models of ATIs on stature SDs were also constructed for the same purpose.

Statistical tests were considered significant if $\mathrm{p}$ values are less than 0.05

The data were analysed using STATA ${ }^{\mathrm{TM}}$ (Version 9.0, Stata Corporation, College station, TX 77845, 800-782-8272).

\section{Results}

\section{Body mass index in the normal boys and girls}

Table 2 shows the BMI distribution by age, gender, trunk symmetry and severe trunk asymmetry. Figure 3 shows the BMI scatter by age in the entire samples of boys and girls.

Body mass index in students with severe trunk asymmetry Figure 4 shows the BMI scatter by age and Figure 5 the boxplots of BMIs for the boys and girls with severe trunk asymmetry by age.

\section{Percentage of TAs outside 2 standard deviations - standing and sitting FB positions}

(Table 3). In the standing FB position, using 2 standard deviations or more to define severe (abnormal) TA, there were: boys, thoracic $4.3 \%$, thoracolumbar $4.1 \%$, lumbar

Table 2: Subjects with symmetry of back shape (normal) and severe trunk asymmetry.

\begin{tabular}{|c|c|c|c|c|}
\hline \multirow[b]{3}{*}{ Age } & \multicolumn{4}{|c|}{ Boys } \\
\hline & \multicolumn{2}{|c|}{ Normal } & \multicolumn{2}{|c|}{ Trunk asymmetry } \\
\hline & Mean & SD & Mean & SD \\
\hline 11 & 20.66 & 4.09 & 19.18 & 3.29 \\
\hline 12 & 21.39 & 4.13 & 20.67 & 4.03 \\
\hline 13 & 22.00 & 4.20 & 21.32 & 3.40 \\
\hline 14 & 22.70 & 4.04 & 21.96 & 3.90 \\
\hline 15 & 22.73 & 3.73 & 22.34 & 3.94 \\
\hline 16 & 22.51 & 4.05 & 25.74 & 5.02 \\
\hline \multirow[t]{2}{*}{17} & 23.72 & 4.01 & 22.52 & 2.72 \\
\hline & \multicolumn{4}{|c|}{ Girls } \\
\hline 11 & 20.57 & 3.84 & 20.33 & 3.24 \\
\hline 12 & 21.55 & 4.01 & 20.37 & 3.77 \\
\hline 13 & 22.44 & 4.19 & 21.20 & 3.24 \\
\hline 14 & 22.72 & 3.86 & 21.66 & 3.40 \\
\hline 15 & 22.50 & 3.69 & 22.44 & 4.39 \\
\hline 16 & 22.40 & 3.21 & 22.04 & 3.44 \\
\hline 17 & 22.15 & 2.85 & 20.90 & $2.4 I$ \\
\hline
\end{tabular}

BMI distribution by age, gender and back shape.
4.3\%; and girls, thoracic 5.9\%, thoracolumbar 5.5\%, lumbar $7.1 \%$. In the sitting FB position, using 2 standard deviations or more to define severe (abnormal) TA, there were: boys, thoracic $5.8 \%$, thoracolumbar $5.4 \%$, lumbar $7.0 \%$; and girls, thoracic $6.7 \%$, thoracolumbar $6.5 \%$, lumbar $6.3 \%$.

\section{Severe TA - comparison by sex in standing and sitting FB positions}

Figures 1 and 2 show the number of boys and girls with ATIs outside 2 SDs in the standing and sitting FB positions for each of the three regions, thoracic, thoracolumbar and lumbar. In the standing FB position the girls are more asymmetric ( $6.93 \%$ vs. $4.28 \%, 5.24 \%$ vs. $4.10 \%$, for thoracic and thoracolumbar regions, respectively), whereas overall in the sitting FB position no statistically significant difference for severe TA was observed between genders.

\section{Severe TA - comparisons by standing and sitting FB positions in boys and girls}

With the exception of the thoracic region in girls, the distribution of TA differed significantly between standing and sitting position in the other spinal regions of the two genders (Table 3). More specifically, TA beyond 2 SDs was always more prevalent in the sitting than in the standing FB position in all spinal regions except the thoracic region of girls.

\section{Severe TA - comparisons by side for sex}

(Table 4) In the standing FB position, the number of boys and girls with ATIs outside 2 SDs collectively for the three regions, thoracic, thoracolumbar and lumbar, is not significantly different between left and right (boys $\mathrm{p}=0.921$, girls $(\mathrm{p}=0.072)$. In the sitting FB position, there is an excess of right relative to left ATIs outside 2 SDs in both boys $(\mathrm{p}=0.020)$ and girls $(\mathrm{p}=0.009)$; and the relative frequency of severe TAs is significantly higher in girls than boys for the right thoracic region (respectively $5.08 \%$ and $4.04 \%, \mathrm{p}=0.006$ ) and right thoracolumbar region (respectively $4.18 \%$ and $4.04 \%, \mathrm{p}=0.023$ ) (Figure 2 ).

\section{Comparison of severe TA in pre- and post-menarcheal girls} Table 5 shows that there is little or no difference in the severity of the severe TAs between boys and girls for position and laterality.

\section{Severe TA - comparisons by relatively lower and relatively higher BMIs}

Figures $6,7,8$ and 9 show the number of boys and girls with ATIs outside 2 SDs in each of the three regions, thoracic, thoracolumbar and lumbar, in standing and sitting FB positions separately for those with relatively higher and relatively lower BMIs.

The relatively lower BMI subsets compared with the relatively higher BMI subsets show: 


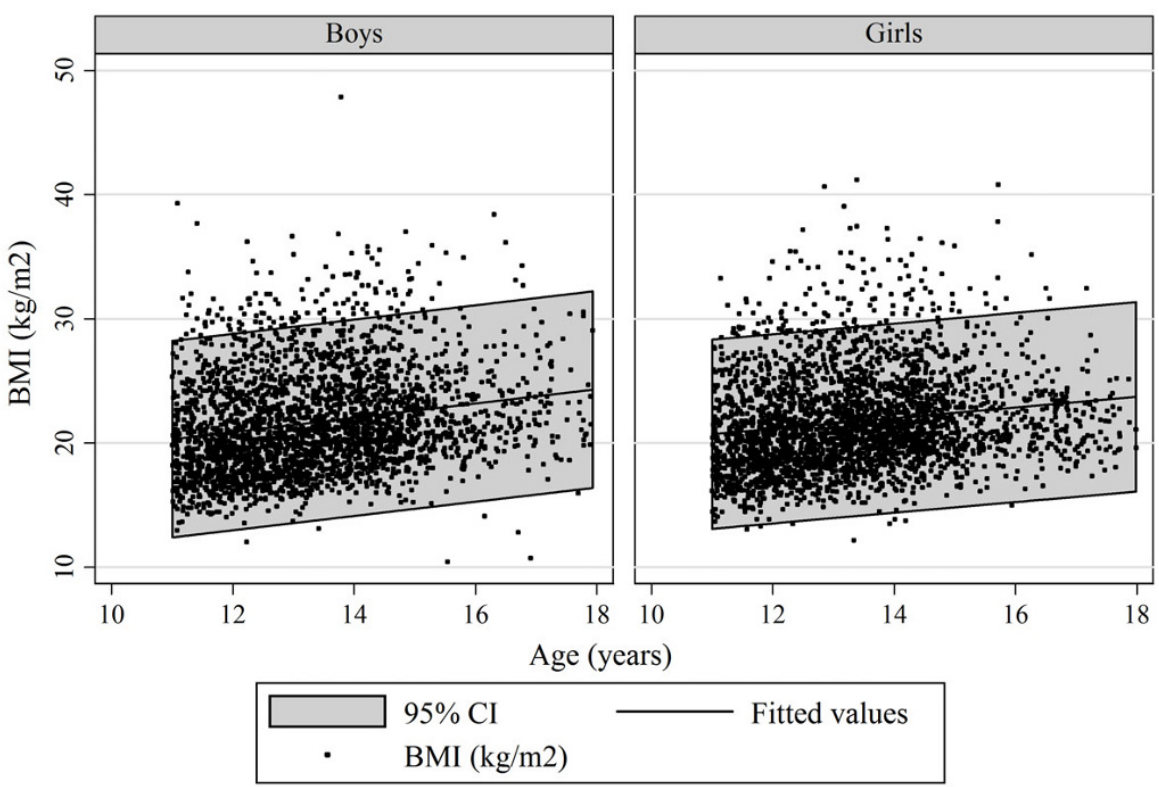

Graphs by gender

Figure 3

All subjects. Scatter plot of BMI by age and gender to show best-fit linear regression and $95 \%$ confidence intervals.

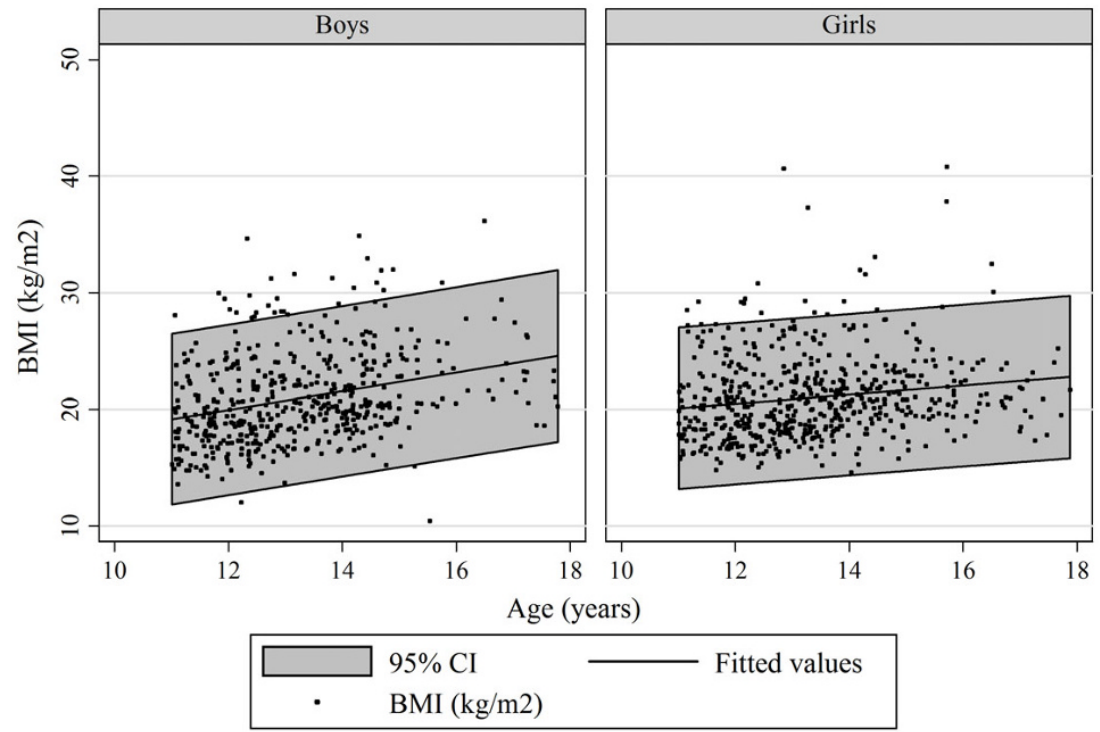

Graphs by gender

Figure 4

Subjects with severe trunk asymmetry. Scatter plot of BMI by age and gender to show best-fit linear regression and $95 \%$ confidence intervals. 

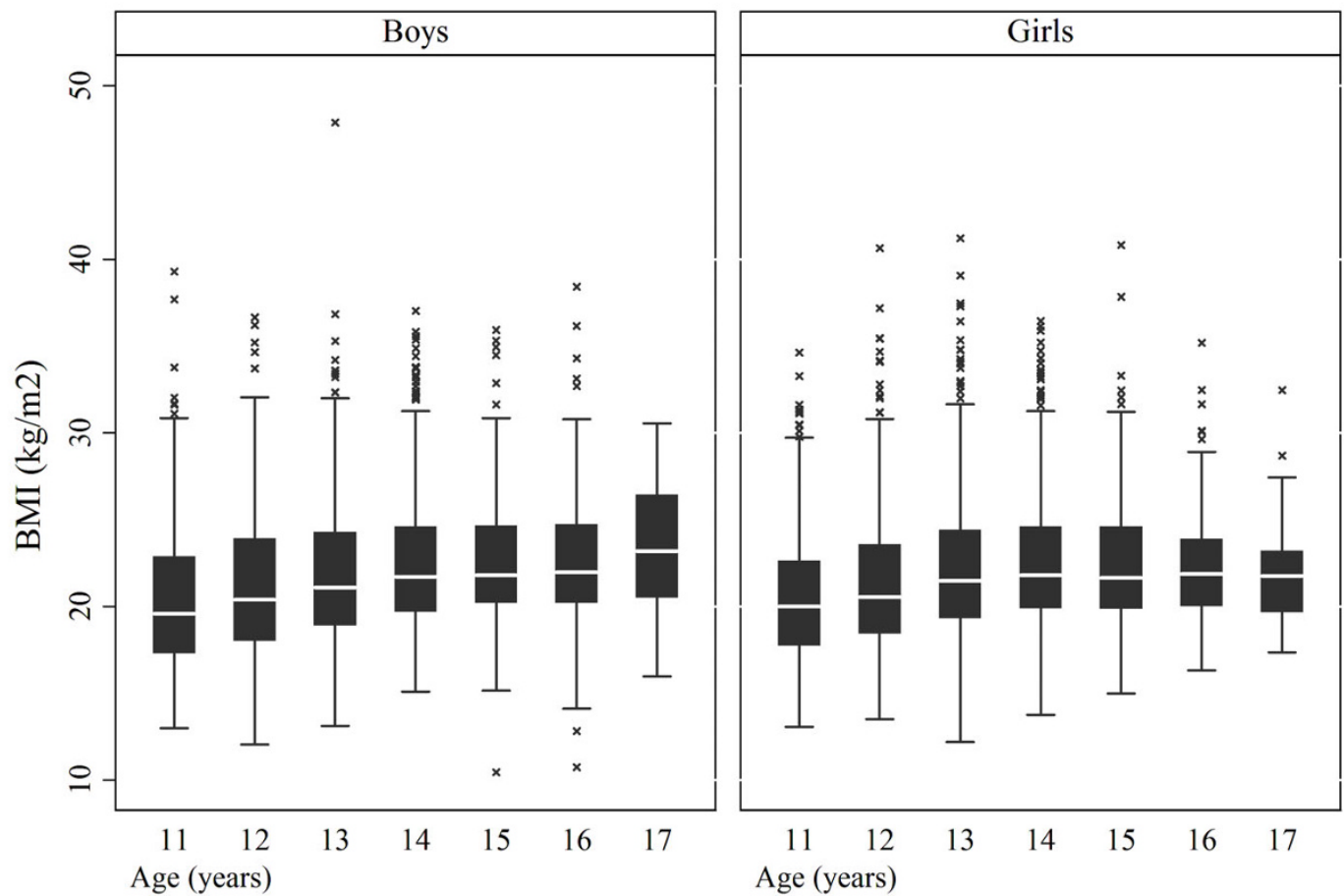

Graphs by gender

Figure 5

Subjects with severe trunk asymmetry. Box plots of BMI by age and gender

Table 3: Subjects with symmetry of back shape (Mean +/- 2 SD) and severe trunk asymmetry (Beyond +/- 2 SD).

\begin{tabular}{|c|c|c|c|c|c|c|}
\hline & & \multicolumn{4}{|c|}{ Boys } & \multirow[b]{3}{*}{$p$} \\
\hline & & \multicolumn{2}{|c|}{ Standing } & \multicolumn{2}{|c|}{ Sitting } & \\
\hline & & Count & Col \% & Count & Col \% & \\
\hline \multirow[t]{2}{*}{ ATI T } & Mean +/- 2 SD & 2696 & 95.70 & 2651 & 94.14 & 0.008 \\
\hline & Beyond +/- 2 SD & 121 & 4.30 & 165 & 5.86 & \\
\hline \multirow[t]{2}{*}{ ATI T-L } & Mean +/- 2 SD & 2701 & 95.88 & 2663 & 94.53 & 0.018 \\
\hline & Beyond +/- 2 SD & 116 & 4.12 & 154 & 5.47 & \\
\hline \multirow[t]{3}{*}{ ATI L } & Mean +/- 2 SD & 2696 & 95.70 & 2617 & 92.93 & $<0.001$ \\
\hline & Beyond +/- 2 SD & 121 & 4.30 & 199 & 7.07 & \\
\hline & & \multicolumn{4}{|c|}{ Girls } & \\
\hline \multirow[t]{2}{*}{ ATI T } & Mean +/- 2 SD & 2726 & 93.04 & 2732 & 93.27 & 0.720 \\
\hline & Beyond +/- 2 SD & 204 & 6.96 & 197 & 6.73 & \\
\hline \multirow[t]{2}{*}{ ATI T-L } & Mean +/- 2 SD & 2776 & 94.74 & 2739 & 93.51 & 0.045 \\
\hline & Beyond +/- 2 SD & 154 & 5.26 & 190 & 6.49 & \\
\hline \multirow[t]{2}{*}{ ATI L } & Mean +/- 2 SD & 2818 & 96.18 & 2746 & 93.75 & $<0.001$ \\
\hline & Beyond +/- 2 SD & 112 & 3.82 & 183 & 6.25 & \\
\hline
\end{tabular}

Distribution of trunk asymmetry (TA) as angles of trunk inclination (ATIs) by forward bending (FB) position, spinal region and gender. 
Table 4: Subjects with symmetry of back shape (Mean +/- 2 SD) and severe trunk asymmetry (Beyond +/- 2 SD).

\begin{tabular}{|c|c|c|c|c|c|c|c|c|c|c|c|}
\hline & & \multicolumn{4}{|c|}{ Boys } & \multicolumn{6}{|c|}{ Girls } \\
\hline & & $\begin{array}{c}\text { Mean +/- } 2 \\
\text { SD }\end{array}$ & $\begin{array}{l}\text { Beyond + } 2 \\
\text { SD (Right) }\end{array}$ & $\begin{array}{c}\text { Beyond - } 2 \\
\text { SD (Left) }\end{array}$ & Total & $p$ & $\begin{array}{l}\text { Mean +/- } 2 \\
\text { SD }\end{array}$ & $\begin{array}{l}\text { Beyond + } 2 \\
\text { SD (Right) }\end{array}$ & $\begin{array}{c}\text { Beyond - } 2 \\
\text { SD (Left) }\end{array}$ & Total & $p$ \\
\hline \multirow{2}{*}{$\begin{array}{l}\mathbf{T} \\
\text { (Standing) }\end{array}$} & Count & 2705 & 57 & 64 & 2826 & 0.921 & 2738 & 143 & 61 & 2942 & 0.072 \\
\hline & Col \% & 95.72 & 2.02 & 2.26 & 100.00 & & 93.07 & 4.86 & 2.07 & 100.00 & \\
\hline \multirow{2}{*}{$\begin{array}{l}\text { TL } \\
\text { (Standing) }\end{array}$} & Count & 2710 & 52 & 64 & 2826 & & 2788 & 90 & 64 & 2942 & \\
\hline & $\mathrm{Col} \%$ & 95.90 & 1.84 & 2.26 & 100.00 & & 94.77 & 3.06 & 2.18 & 100.00 & \\
\hline \multirow{2}{*}{$\begin{array}{l}\mathbf{L} \\
\text { (Standing) }\end{array}$} & Count & 2704 & 57 & 64 & 2825 & & 2830 & 73 & 39 & 2942 & \\
\hline & $\mathrm{Col} \%$ & 95.72 & 2.02 & 2.27 & 100.00 & & 96.19 & 2.48 & 1.33 & 100.00 & \\
\hline \multirow[t]{2}{*}{$\mathbf{T}$ (Sitting) } & Count & 2659 & 112 & 53 & 2824 & 0.020 & 2744 & 147 & 50 & 2941 & 0.009 \\
\hline & $\mathrm{Col} \%$ & 94.16 & 3.97 & 1.88 & 100.00 & & 93.30 & 5.00 & 1.70 & 100.00 & \\
\hline \multirow{2}{*}{$\begin{array}{l}\text { TL } \\
\text { (Sitting) }\end{array}$} & Count & 2671 & 84 & 70 & 2825 & & $275 I$ & 120 & 70 & 2941 & \\
\hline & Col \% & 94.55 & 2.97 & 2.48 & 100.00 & & 93.54 & 4.08 & 2.38 & 100.00 & \\
\hline \multirow[t]{2}{*}{ L (Sitting) } & Count & 2625 & 110 & 89 & 2824 & & 2757 & 112 & 72 & 2941 & \\
\hline & $\mathrm{Col} \%$ & 92.95 & 3.90 & 3.15 & 100.00 & & 93.74 & 3.81 & 2.45 & 100.00 & \\
\hline
\end{tabular}

Comparison of ATls beyond 2 SDs in standing and sitting FB positions for each gender by spinal region and side.

- in the standing FB position, for each of boys (Figure 6, thoracic and thoracolumbar) and girls (Figure 7, thoracic and thoracolumbar), an excess of severe TA at each of these two levels.

- in the sitting FB position, an excess of severe TA at each of two levels in boys (Figure 8, thoracolumbar and lumbar) and one level in girls (Figure 9, thoracolumbar).

\section{BMIs and association with severe TA}

Table 6 shows that in the sitting FB position after correcting for age, BMI is associated significantly and negatively with thoracic TA in boys $(\mathrm{p}=0.001)$ and girls $(\mathrm{p}=0.030)$, i.e smaller BMIs are associated with more severe TAs.

In addition, a significant inverse association between BMI and humps was found in boys (lumbar region, sitting FB position, $\mathrm{p}=0.013$ ) and in girls (thoracic, lumbar regions in standing $\mathrm{FB}$ position, $\mathrm{p}=0.034, \mathrm{p}=0.009$, respectively).

\section{Menarcheal age and BMI}

Overall, the mean age (and standard deviation) at menarche was $11.82 \pm 1.26$. Menarcheal age is significantly earlier in the higher BMI subset, than in the lower BMI subset (mean and SD respectively $11.61 \pm 1.26$ years and $12.10 \pm 1.21$ years, $\mathrm{p}<0.001, \mathrm{n}=735$ and 982 respectively = 1717) (overall premenarcheal 1221, 517 and 704 in higher and lower BMI subset respectively).

Comparison of severe TA in pre- and post-menarcheal girls Table 7 shows significantly more right than left humps in the sitting FB position in the lumbar region of postmenarcheal girls $(\mathrm{p}=0.022)$, to be contrasted with an equal distribution of right and left TAs of premenarcheal girls in the lumbar region.

\section{Discussion}

Intrinsic back shape asymmetry (Figure 2, Table 4)

The girls and boys in the sitting FB position show a similar magnitude of severe TAs with significantly more TAs on the right (Figure 2). The relative frequency of severe TAs is significantly higher in girls than boys for each of the right thoracic and thoracolumbar regions (Figure 2). There is little or no difference in the magnitude of severe TAs between boys and girls (Table 5).

Body mass index (BMI) in children screened for scoliosis Our findings confirm that BMI is normal in children screened for scoliosis (Figure 3) [7,16,23-25]. BMI is reported to be normal before scoliosis develops [24,25]. While in general use as an indicator of adiposity and readily calculated, BMI needs further evaluation [57]. 
Table 5: Subjects with severe trunk asymmetry.

\begin{tabular}{|c|c|c|c|c|c|c|c|c|c|}
\hline & & & \multicolumn{4}{|c|}{ Gender } & \multicolumn{3}{|l|}{ Total } \\
\hline & & & \multicolumn{2}{|c|}{ Boys } & \multicolumn{2}{|r|}{ Girls } & \multirow[t]{2}{*}{ Mean } & \multicolumn{2}{|c|}{ Std Deviation } \\
\hline & & & Mean & Std Deviation & Mean & Std Deviation & & & $\mathbf{p}$ \\
\hline \multirow[t]{6}{*}{ Standing } & $\mathrm{T}$ & Right & 7.74 & 1.01 & 8.21 & 1.91 & 8.09 & 1.75 & 0.267 \\
\hline & & Left & 7.91 & 1.92 & 9.00 & 1.70 & 8.43 & 1.86 & 0.183 \\
\hline & TL & Right & 8.56 & 3.01 & 8.55 & 2.04 & 8.55 & 2.42 & 0.982 \\
\hline & & Left & 8.03 & 1.32 & 9.15 & 2.40 & 8.56 & 1.98 & 0.016 \\
\hline & $\mathrm{L}$ & Right & 8.03 & 1.30 & 8.14 & 1.64 & 8.10 & 1.51 & 0.733 \\
\hline & & Left & 8.06 & 1.66 & 13.24 & 12.44 & 9.86 & 7.72 & 0.107 \\
\hline \multirow[t]{6}{*}{ Sitting } & $\mathrm{T}$ & Right & 7.87 & 1.25 & 8.54 & 1.80 & 8.35 & 1.68 & 0.132 \\
\hline & & Left & & feasible & & & & & \\
\hline & TL & Right & 8.67 & 1.39 & 8.77 & 2.44 & 8.74 & 2.21 & 0.859 \\
\hline & & Left & 8.31 & 1.40 & 8.06 & 1.48 & 8.19 & 1.42 & 0.627 \\
\hline & $\mathrm{L}$ & Right & 8.43 & 1.89 & 8.93 & 2.35 & 8.68 & 2.13 & 0.367 \\
\hline & & Left & 9.35 & 3.64 & 8.18 & 1.72 & 8.89 & 3.05 & 0.330 \\
\hline
\end{tabular}

Comparison of mean values of TA by gender, spinal region and laterality.

Relatively earlier menarche with relatively higher BMIs

The earlier menarche of the higher relative to the lower BMI subset confirms findings for scoliosis screening referrals [23]. Several studies of normal girls show a relationship between BMI and measures of pubertal onset, and girls with relatively higher BMI are more likely to have earlier menarche $[58,59]$. Our findings are consistent with knowledge of a link between body fat and the timing of puberty with (1) leptin playing a permissive role $[58,59]$, and (2) kisspeptin providing a critical metabolic signal initiating puberty through pulsatile GnRH secretion [59-62] by activating the G-protein coupled receptor-54 [61]. BMI in girls is said to be a good although imperfect surrogate measure of body fat [59]. In boys, few studies have found a link between body fat and earlier puberty [59]. We have no puberty maturity data for boys by which to asses whether puberty was earlier in their higher BMI subset.

\section{How may the lower BMI subset of girls with later menarche be related to the excess of severe TAs in the sitting FB position?}

The girls with relatively lower BMI are associated statistically with each of (1) significantly later menarche, (2) excess of premenarcheal girls, and (3) significant excess of severe TA (Figures 8 \&9). Smaller BMIs are associated with more severe TAs after correcting for age (Table 6). The linkage of lower BMI with TA has not been reported, but it extends observations on girls with AIS and relatively lower $B M I$, namely $[23,30]$ :

(1) girls with right thoracic AIS show statistically significant associations of each of Cobb angle and apical vertebral rotation with upper limb length asymmetry (upper arms); and

(2) preoperative girls show upper arm length asymmetry significantly greater than in screened and normal girls.

These observations and other evidence from screened and normal girls suggested that girls with AIS have a dysfunctional energy balance involving the hypothalamus [23,27301 . Bodily energy reserves are managed actively by powerful and unconscious complex systems that regulate food intake, substrate partitioning, and energy expenditure [63]. The complex systems include white adipose tissue, the adipose-tissue derived hormone leptin (and other cytokine-hormones), hypothalamus, and neuroendocrine axes including the sympathetic nervous system $[63,64]$. Energy balance (bioenergetics) is known to influence 
Boys 11-17 years standing forward bending ATIs: number without \& within 2 SDs by site and BMI subset $(n=2817)$
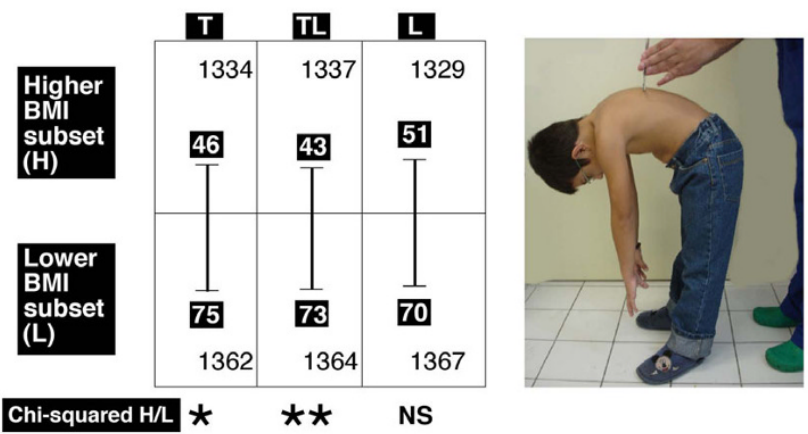

Figure 6

Boys I I-I 7 years. Standing forward bending position. Angle of trunk inclinations, number outside and within 2 standard deviations by site and BMI subset $(n=28 I 7)$. Note there is significantly more severe TA in the lower BMl subset relative to the higher $\mathrm{BMI}$ subset for thoracic $(T)$ and thoracolumbar $(\mathrm{TL})$ but not lumbar $(\mathrm{L})$ regions. $*=0.01<\mathrm{P}<$ $0.05, * *=.001<P<0.01$, NS = not significant.

\section{Girls 11-17 years standing forward bending} ATIs: number without \& within 2 SDs by site and BMI subset $(n=2930)$

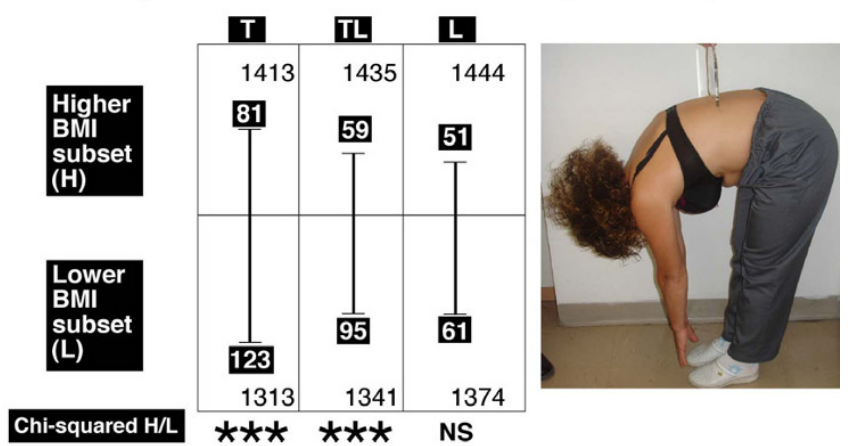

Figure 7

Girls I I-I 7 years. Standing forward bending position. Angle of trunk inclinations, number outside and within \pm 2 standard deviations by site and BMI subset $(n=2930)$. Note there is significantly more severe TA in the lower BMI subset relative to the higher $B M I$ subset for thoracic $(T)$ and thoracolumbar $(\mathrm{TL})$ but not lumbar $(\mathrm{L})$ regions. $* * *=\mathrm{P}<0.00 \mathrm{I}$, NS = not significant.

\section{Boys 11-17 years sitting forward bending ATIs: number without \& within 2 SDs by site and BMI subset $(n=2816 / 7)$}

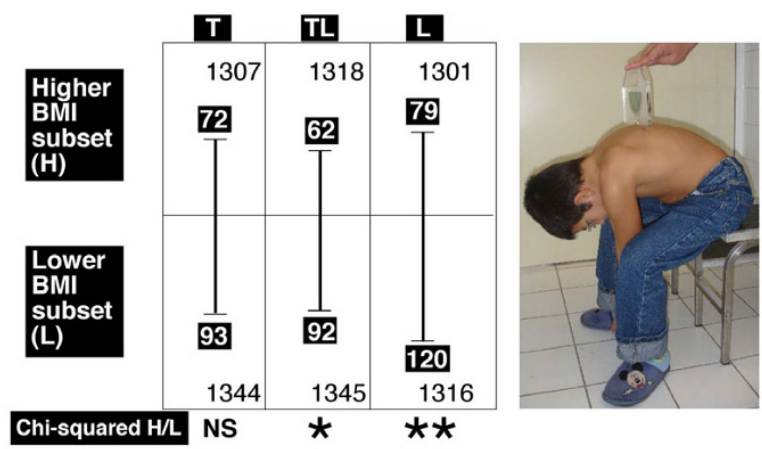

Figure 8

Boys I I-I 7 years. Sitting forward bending position. Angle of trunk inclinations, number outside and within 2 standard deviations by site and BMI subset $(n=2816 / 7)$. Note there is significantly more severe TA in the lower BMI subset relative to the higher BMl subset for thoracolumbar (TL) and lumbar (L) but not thoracic $(\mathrm{T})$ region. $*=0.0 \mathrm{I}<\mathrm{P}<0.05, * *=.00 \mathrm{I}$ $<P<0.01$, NS = not significant.

\section{Girls 11-17 years sitting forward bending ATIs: number without \& within 2 SDs by site and BMI subset $(n=2929)$}

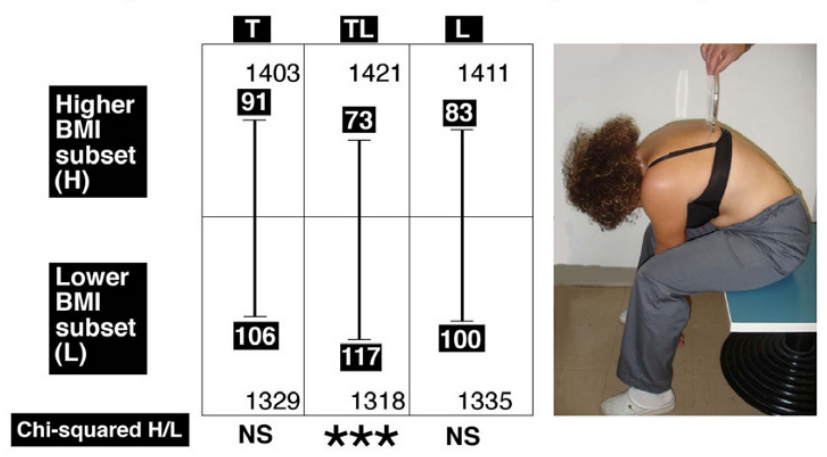

\section{Figure 9}

Girls I I-I 7 years. Sitting forward bending position. Angle of trunk inclinations, number outside and within 2 standard deviations by site and BMI subset $(n=2929)$. Note there is significantly more severe TA in the lower BMI subset relative to the higher $\mathrm{BMI}$ subset for thoracolumbar $(\mathrm{TL})$ but not thoracic $(\mathrm{T})$ and lumbar $(\mathrm{L})$ regions. $* * *=\mathrm{P}<0.00 \mathrm{I}, \mathrm{NS}=$ not significant. 
Table 6: All subjects

\begin{tabular}{|c|c|c|c|c|c|c|c|c|c|c|}
\hline Position & $\begin{array}{l}\text { Dependent } \\
\text { variable }\end{array}$ & $\begin{array}{l}\text { Explanatory } \\
\text { variable }\end{array}$ & $\begin{array}{l}\text { Unstandardised } \\
\text { beta coefficient }\end{array}$ & [95\% Conf. & Interval] & $p$ & $\begin{array}{l}\text { Unstandardised } \\
\text { beta coefficient }\end{array}$ & [95\% Conf. & Interval] & $p$ \\
\hline & & & & Boys & & & & Girls & & \\
\hline \multirow{9}{*}{$\begin{array}{l}\text { Standing } \\
\text { position }\end{array}$} & ATI T & BMI & -0.01 & -0.03 & 0.01 & 0.366 & -0.02 & -0.05 & 0.00 & 0.034 \\
\hline & & Age & 0.05 & 0.00 & 0.10 & 0.077 & 0.05 & -0.01 & 0.11 & 0.089 \\
\hline & & Constant & -0.21 & -0.92 & 0.51 & 0.566 & 0.34 & -0.51 & 1.18 & 0.435 \\
\hline & ATI T-L & BMI & 0.01 & -0.02 & 0.03 & 0.604 & -0.02 & -0.05 & 0.01 & 0.142 \\
\hline & & Age & 0.03 & -0.03 & 0.10 & 0.335 & 0.03 & -0.04 & 0.10 & 0.444 \\
\hline & & Constant & -0.33 & -1.26 & 0.61 & 0.495 & 0.51 & -0.51 & 1.53 & 0.323 \\
\hline & ATI L & BMI & 0.01 & -0.01 & 0.03 & 0.306 & -0.03 & -0.06 & -0.01 & 0.009 \\
\hline & & Age & 0.00 & -0.06 & 0.06 & 0.915 & 0.00 & -0.06 & 0.07 & 0.930 \\
\hline & & Constant & -0.07 & -0.91 & 0.78 & 0.879 & 1.05 & 0.10 & 2.00 & 0.031 \\
\hline \multirow{9}{*}{$\begin{array}{l}\text { Sitting } \\
\text { position }\end{array}$} & ATI T & BMI & -0.02 & -0.04 & -0.01 & 0.001 & -0.02 & -0.04 & 0.00 & 0.030 \\
\hline & & Age & 0.06 & 0.02 & 0.10 & 0.004 & 0.08 & 0.04 & 0.13 & $\begin{array}{c}<0.00 \\
1\end{array}$ \\
\hline & & Constant & -0.02 & -0.58 & 0.54 & 0.946 & -0.32 & -0.97 & 0.32 & 0.326 \\
\hline & ATI T-L & BMI & -0.01 & -0.03 & 0.01 & 0.298 & 0.00 & -0.02 & 0.02 & 0.727 \\
\hline & & Age & 0.05 & 0.00 & 0.10 & 0.042 & 0.06 & 0.01 & 0.12 & 0.029 \\
\hline & & Constant & -0.23 & -0.95 & 0.48 & 0.527 & -0.40 & -1.20 & 0.40 & 0.331 \\
\hline & ATI L & BMI & -0.02 & -0.04 & -0.01 & 0.013 & 0.00 & -0.02 & 0.02 & 0.863 \\
\hline & & Age & 0.01 & -0.04 & 0.06 & 0.762 & 0.01 & -0.04 & 0.06 & 0.775 \\
\hline & & Constant & 0.66 & -0.08 & 1.40 & 0.081 & 0.24 & -0.47 & 0.94 & 0.514 \\
\hline
\end{tabular}

Regression of BMI on angle of trunk inclination (ATI) with adjustment for age (age constant) in standing and sitting FB positions by gender and spinal region.

bone formation, resorption and bone growth in mice [64$66]$, and there is evidence suggesting it does so in children $[23,30,67]$.

We apply the hypothesis of pathogenesis proposed for girls with AIS $[23,30]$ to girls and boys with severe TAs, namely: TAs are caused by a genetically-determined selectively increased hypothalamic sensitivity (up-regulation) to leptin with asymmetry as an adverse response (LHS concept). This hypothalamic functional asymmetry is expressed bilaterally via the sympathetic nervous system mainly to the growing trunk to produce left-right asymmetry in ribs and/or vertebrae leading to severe TAs, when beyond the capacity of postural mechanisms of the somatic nervous system to control the shape distortion in the trunk (neuroosseous escalator concept) [68].

The evidence of Qiu et al [21] confirmed by Moreau (Dr A Moreau personal communication), suggests that the lower BMI subsets of the girls and boys in our study had relatively lower circulating leptin levels than those with relatively higher BMIs. If so, the lower circulating leptin levels may have exacerbated the hypothalamic processes including asymmetry leading to the excess of severe TA in the lower BMI subsets.

We suggest that the majority of girls and boys with TA who do not progress to AIS [24], may have less severe involvement of their autonomic and somatic nervous systems. They may also lack hormonal changes [30] and osteopenia $[69,70]$ posited to contribute to the curve severity of preoperative girls with AIS [30] in the biomechanical spinal growth modulation of progressive AIS [71-73].

\section{LHS concept, melatonin-signaling pathway dysfunction, osteopontin and SCD44}

In progressive AIS, Moreau and colleagues [74,75] reported melatonin-signaling transduction to be impaired in osteoblasts, myoblasts and lymphocytes, caused by the dysfunction of $G$ inhibitory (Gi) proteins. This mechanism does not appear to explain: 
Table 7: Girls with severe trunk asymmetry

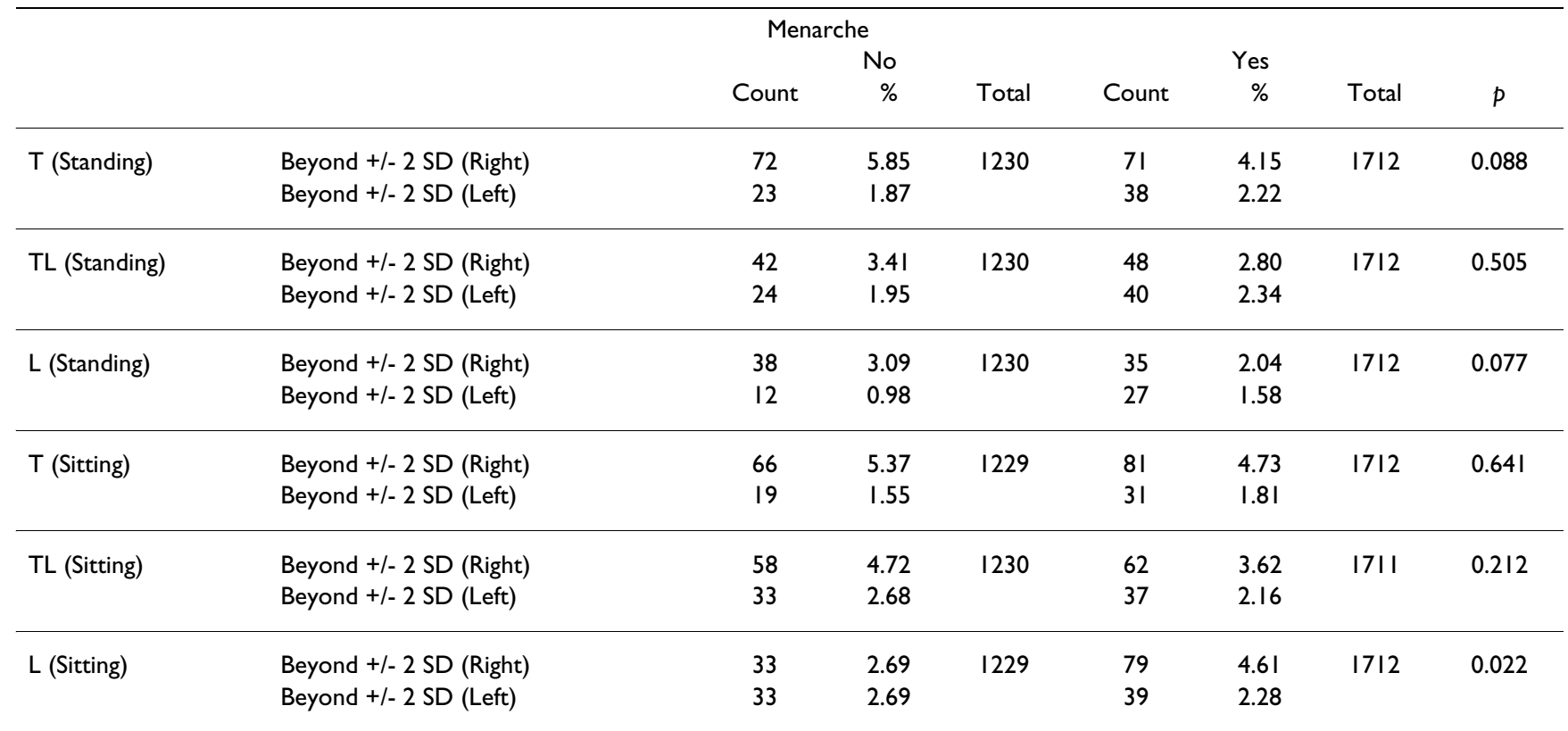

Numbers premenarcheal and postmenarcheal in standing and sitting FB positions by back hump laterality and spinal region.

- the association of an excess of severe TA with relatively lower BMI suggesting a link with energy homeostasis (this paper); and

- disturbance in the autonomic nervous system regulating blood flow to the anterior chest wall in girls with right thoracic AIS [76-79] - unless the sympathetic nervous system also has Gi-signaling defect, or induces a Gi-signaling defect in growth plates and bone (see below).

Most recently, Moreau et al $[80,81]$ report mean plasma osteopontin (OPN) levels are increased in patients with (1) idiopathic scoliosis, correlating significantly with curve severity, and in (2) "an asymptomatic at-risk group" (offspring born from at least one scoliotic parent). In contrast, mean plasma levels of soluble CD44 receptor (sCD44) are significantly lower in patients with Cobb angles of 45 degrees or more $[80,81]$. No OPN or sCD44 data are published for non-familial TA with or without spinal deformity.

Age at which severe TA become detectable in girls and boys TAs in normal children become evident in juvenility, earlier in girls than boys [45]. Normal juveniles are more symmetric in back shape than are adolescents with girls more symmetric than boys. Increase in TA takes place in girls at 6-7 and 8-9 years and in boys at 8-9 years [45]. We suggest this developing TA involves energy balance controlled by the hypothalamus starting its preparations for puberty.
The greater susceptibility of girls than boys to progressive AIS is attributed to a greater down-regulation (i.e. central resistance) to leptin of the female hypothalamus established in hominin evolution $[28,30]$. Hence, hypothalamic up-regulation (i.e central sensitivity) with its asymmetries contributing to AIS should be greater in girls than boys. Consistent with this prediction is finding that the relative frequency of severe TAs is significantly higher in girls than boys for the right thoracic and thoracolumbar regions [Figure 2 and Table 4 where right relative to left ATIs outside 2 SDs in both boys $(\mathrm{p}=0.020)$ and girls $(\mathrm{p}=$ $0.009)]$, but the girls' severe TAs are not more severe than those of the boys (Table 5).

\section{Musculo-skeletal mechanisms in the trunk that may determine TAs in normal girls and boys}

Mechanical factors involving ribs and/or vertebrae and spinal cord during growth may localize AIS to the thoracic spine [30] and contribute to its sagittal spinal shape alterations [82-84]. The musculo-skeletal mechanisms that may initiate TAs - thoracic, thoracolumbar and lumbar of normal adolescents are unknown. It is improbable that either relative anterior spinal overgrowth [82-86] or asynchronous spinal neuro-osseous growth $[26,87-89]$ could determine TAs. Possibilities include dorsal shear forces, with axial vertebral rotation $[44,52,53]$ and neuromuscular mechanisms acting dysfunctionally on vertebral and rib growth. More likely are growth processes involving ribs $[9,90]$ with the rib cage deformity preceding the spinal deformity [48]. In the normal adult, pre-existing thoracic axial vertebral rotation, usually to the right, has been 
demonstrated and accounted for by asymmetrical anatomy of thoracic organs [52]. This axial vertebral rotation may be contributed to by asymmetrical growth in one or more neurocentral synchondroses [90-94], vertebral body torsion $[95,96]$ and/or ribs $[9,47,48,76,90,97-100]$.

\section{Thoraco-spinal pathogenetic concept for right thoracic (RT) AIS in girls}

The LHS concept extends, and provides a wider scientific framework for, the thoraco-spinal pathogenetic concept for right thoracic (RT) AIS of girls [76,97,98]. A longitudinal study of anterior chest wall blood supply of girls with progressive right thoracic (RT) AIS, supports the view that RT AIS in females is associated with a disturbance in the autonomic nervous system regulating blood flow to the anterior chest wall $[77,78]$. The thoraco-spinal concept is supported by recent peripheral nerve studies [79].

\section{Lower spine AIS and hormesis}

In lower spine AIS (thoracolumbar and lumbar curves), iliac height is greater on the curve concavity $[101,102]$. In AIS girls with such curves, iliac height asymmetry and apical vertebral rotation, each correlate positively with BMI like the 'dose' of a hormetic effect [103]. Given that BMI may be a surrogate measure for leptin [21], these findings are consistent with the phenomenon of hormesis [104]; that is a bimodal dose response, first stimulation and then an adverse response, usually inhibition, to drugs, toxins and a hormone such as leptin. In rats, infused leptin increases sympathoactivation in a dose-dependent manner suggesting that leptin may act hormetically on the normal rat hypothalamus [105]. In AIS girls with lower spine scoliosis, the LHS concept postulates that the left-right iliac length asymmetries result from an adverse hormetic response to leptin in the hypothalamus [103], a suggestion considered plausible [Calabrese E, personal communication].

\section{Rett syndrome}

In the Rett syndrome, raised circulating leptin levels and overactivity of the sympathetic nervous system are pathophysiological features of this genetic neurodevelopmental disorder [106]. In patients with Rett syndrome, the skin sympathetic responses were reported to show relatively lower amplitude on the foot ipsilateral to the convex side of the scoliosis [107]. Skin sympathetic responses need studying in AIS girls with the recording electrodes placed on both sides of the trunk and at other sites [30].

\section{Test of the hypothesis}

A test of the autonomic component of the hypothesis testing skin sympathetic responses [107] in students with severe TAs is suggested.

\section{Conclusion}

(1) The relation between truncal asymmetry (TA), body mass index (BMI) and menarcheal status is evaluated in healthy adolescents age 11-17 years (boys 2817, girls 2930) (Table 1).

(2) Each child was assigned a value of "lower" or "higher" $B M I$ relative to median values constructed for each age group, gender, position and spinal region.

(3) The sitting FB position is thought to express intrinsic TA free from extrinsically-induced effects of any leg-length inequality. The analyses of the findings for the pathogenetic interpretation utilise these data.

(4) In the sitting FB position for severe TA:

a) There is no sex difference in TAs for any of the three spinal regions.

b) An excess of right relative to left ATIs outside 2 SDs in both boys $(\mathrm{p}=0.020)$ and girls $(\mathrm{p}=0.009)$.

c) The relative frequency of severe TAs is significantly higher in girls than boys for each of the right thoracic and thoracolumbar regions (Figure 2 and Table 4).

d) After correcting for age, smaller BMIs associated with more severe TAs in boys and girls (Table 6).

(5) Mean age at menarche was significantly later in the lower BMI subset, than in the higher BMI subset (mean and SD respectively $12.10 \pm 1.21$ years, and $11.61 \pm 1.26$ years, $\mathrm{p}<0.001)$.

(6) The girls with relatively lower BMI are associated with significantly later menarche, and a significant excess of TAs. These observations together with other evidence $[23,30]$, suggests a relation of trunk asymmetry to energy balance through the hypothalamus.

(7) As with a recent hypothesis for the pathogenesis of AIS in girls $[27,30]$, we suggest that severe TAs are caused by a genetically-determined selectively increased sensitivity (up-regulation, i.e. increased sensitivity) of the hypothalamus to leptin with asymmetry as an adverse response to stress, increased by lower circulating leptin levels associated with relatively lower BMIs (LHS concept). This hypothalamic functional asymmetry is expressed via the sympathetic nervous system bilaterally to produce left-right asymmetry in ribs and/or vertebrae leading to severe $\mathrm{TA}$, when beyond the capacity of postural mechanisms of the somatic nervous system to control the shape distortion in the trunk. 
(8) We suggest that the majority of girls and boys with TA who do not progress to AIS [24], may have less severe involvement of their autonomic and somatic nervous systems. They may also lack hormonal changes [30] and osteopenia [69] both of which may contribute to the curve severity of preoperative girls with AIS [30] in the biomechanical spinal growth modulation of progressive AIS [7173].

\section{Competing interests}

The authors declare that they have no competing interests.

\section{Authors' contributions}

TBG proposed the idea of the presented study, performed part of the literature review, contributed to the interpretation of data and in drafting the manuscript. RGB guided parts of the analysis, contributed to the literature review, interpreting the data and drafting the manuscript. $\mathrm{CM}$ contributed in the statistical analysis and drafting the manuscript. ESV performed part of the literature review and participated in the school screening program. GT and AK participated in the school screening program. All authors read and approved the final manuscript.

\section{Acknowledgements}

Parental consent was obtained before the examination and photography of children at school.

The authors express their appreciation to Mrs C Maziotou for her valuable help to run the "Thriaso" school screening program, Professor FJP Ebling, Professor of Neuroendocrinology and Dr SI Anderson both of the School of Biomedical Sciences, University of Nottingham, UK, for discussions, and Mr Lyndon Cochrane, medical artist, for the Figures. Dr Alain Moreau discussed his research with Professor RG Burwell on 24th April 2009 and subsequently by e-mail for which we thank him.

\section{References}

I. Bunnell WP: An objective criterion for scoliosis screening. J Bone Joint Surg Am 1984, 66(9): I 381-7.

2. Bunnell WP: Selective screening for scoliosis. Clin Orthop Relat Res 2005, 434:40-5.

3. Grivas TB, Vasiliadis ES, Rodopoulos G: Aetiology of idiopathic scoliosis. What have we learned from school screening? Stud Health Technol Inform 2008, 140:240-4.

4. Grivas TB, Vasiliadis E, Savvidou OD, Triantafyllopoulos G: What a school screening program could contribute in clinical research of idiopathic scoliosis aetiology. Disabil Rehabil 2008, 30(I0):752-62.

5. Grivas TB, Vasiliadis ES, Rodopoulos G, Kovanis I: School screening as a research tool in epidemiology, natural history and aetiology of idiopathic scoliosis. Stud Health Technol Inform 2008, 135:84-93.

6. Grivas TB, Samelis P, Pappa AS, Stavlas P, Polyzois D: Menarche in scoliotic and nonscoliotic Mediterranean girls. Is there any relation between menarche and laterality of scoliotic curves? Stud Health Technol Inform 2002, 88:30-6.

7. Milenkovic SM, Kocijancic RI, Belojevic GA: Left handedness and spine deformities in early adolescence. Eur J Epidemiol 2004 19(10):969-72.

8. Grivas TB, Vasiliadis ES, Polyzois VD, Mouzakis V: Trunk asymmetry and handedness in 8245 school children. PediatrRehabil 2006, 9(3):259-66.

9. Grivas TB, Dangas S, Polyzois BD, Samelis P: The double rib contour sign (DRCS) in lateral spinal radiographs: aetiologic implications for scoliosis. Stud Health Technol Inform 2002, 88:38-43.

10. Grivas TB, Savvidou OD: Melatonin the "light of night" in human biology and adolescent idiopathic scoliosis. Scoliosis. 2007 Apr 4;2:6 2007, 2:6.

II. Grivas TB, Vasiliadis E, Savvidou O, Mouzakis V, Koufopoulos G: Geographic latitude and prevalence of adolescent idiopathic scoliosis. Stud Health Technol Inform 2006, I 23:84-9.

12. Grivas TB, Samelis P, Polyzois BD, Giourelis B, Polyzois D: School screening in the heavily industrialized area - Is there any role of industrial environmental factors in idiopathic scoliosis prevalence? Stud Health Technol Inform 2002, 91:76-80.

13. Grivas TB, Vasiliadis E, Mouzakis V, Mihas C, Koufopoulos G: Association between adolescent idiopathic scoliosis prevalence and age at menarche in different geographic latitudes. Scoliosis 2006, 1:9.

14. Shohat M, Shohat T, Nitzan M, Mimouni M, Kedem R, Danon YL: Growth and ethnicity in scoliosis. Acta Orthop Scand 1988, 59(3):3|0-3|3.

15. Cole AA, Burwell RG, Dangerfield PH, Grivas TB, Webb JK, Moulton A: Anthropometry. In Etiology of Adolescent Idiopathic Scoliosis: Current Trends and Relevance to New Treatment Approaches State of the Art Reviews: Spine Volume 14. Issue 2 Edited by: Burwell RG, Dangerfield PH, Lowe TG, Margulies JY. Philadelphia, Hanley \& Belfus Inc; 2000:4II-42|

16. Grivas TB, Arvaniti A, Maziotou C, Manesioti M, Fergadi A: Comparison of body weight and height between normal and scoliotic children. Stud Health Technol Inform 2002, 91:47-53.

17. Smith FM, Latchford G, Hall RM, Millner PA, Dickson RA: Indications of disordered eating behaviour in adolescents with idiopathic scoliosis. J Bone Joint Surg Br 2002, 84(3):392-4.

18. Davey RC, Cochrane T, Dangerfield PH, Chockalingam N, Dorgan JC: Anthropometry and body composition in females with adolescent idiopathic scoliosis. In International Research Society of Spinal Deformities Symposium 2004 Edited by: Sawatzky BJ. University of British Columbia; 2004:323-326.

19. Cheung CSK, Lee WTK, Tse YK, Lee KM, Guo X, Qin L, Cheng JCY: Generalized osteopenia in adolescent idiopathic scoliosis association with abnormal pubertal growth, bone turnover, and calcium intake? Spine 2006, 3 I (2):330-338.

20. Suh KT, Lee S-S, Hwang SH, Kim SJ, Lee JS: Elevated soluble receptor activity of nuclear factor-kB ligand and reduced bone mineral density in patients with adolescent idiopathic scoliosis. Eur Spine J 2007, 16:1563-1569.

21. Oiu Y, Sun X Qiu X, Li W, Zhu Z, Zhu F, Wang B, Yu Y, Qian B. Decreased circulating leptin level and its association withbody and bone mass in girls with adolescent idiopathic scoliosis. Spine 2007, 32(24):2703-10.

22. Smith FM, Latchford G], Hall RM, Dickson RA: Do chronic medical conditions increase the risk of eating disorder? A cross-sectional investigation of eating pathology in adolescent females with scoliosis and diabetes. J Adolesc Health 2008, 42(I):58-63.

23. Burwell RG, Aujla RK, Kirby AS, Dangerfield PH, Moulton A, Cole AA, Polak FJ, Pratt RK, Webb JK: Body mass index of girls in health influences menarche and skeletal maturation: a leptin-sympathetic nervous system focus on the trunk with hypothalamic asymmetric dysfunction in the pathogenesis of adolescent idiopathic scoliosis? Stud Health Technol Inform 2008, 140:9-21.

24. Nissinen M, Heliövaara M, Seitsamo J, Poussa M: Trunk asymmetry, posture, growth, and risk of scoliosis. A three-year follow-up of Finnish prepubertal school children. Spine 1993, I8(I):8-13.

25. Nissinen M, Heliövaara M, Ylikoski M, Poussa M: Trunk asymmetry and screening for scoliosis: a longitudinal cohort study of pubertal schoolchildren. Acta Paediatr 1993, 82(1):77-82.

26. Burwell RG, Dangerfield PH, Freeman BJ: Concepts on the pathogenesis of adolescent idiopathic scoliosis. Bone growth and mass, vertebral column, spinal cord, brain, skull, extra-spinal left-right skeletal length asymmetries, disproportions and molecular pathogenesis. Stud Health Technol Inform 2008, 135:3-52.

27. Burwell RG, Dangerfield PH, Moulton A, Anderson SI: Etiologic theories of idiopathic scoliosis: autonomic nervous system and the leptin-sympathetic nervous system concept for the 
pathogenesis of adolescent idiopathic scoliosis. Stud Health Technol Inform 2008, I 40:197-207.

28. Burwell RG, Aujla RK, Kirby AS, Dangerfield PH, Moulton A, Cole AA, Polak FJ, Pratt RK, Webb JK: Etiologic theories of idiopathic scoliosis: the leptin-hypothalamic-sympathetic nervous system (LHS) mechanism of normal trunk width growth in girls - evolutionary origin, energy allocation, motor pathways, dysfunction and pathogenesis [Abstract]. In Proceedings of the International Research Society of Spinal Deformities Hope University, Everton Campus, Liverpool, UK, Abstract Book; 2008:2I.

29. Burwell RG, Aujla RK, Grevitt MP, Dangerfield PH, Moulton A, Anderson SI: Pathogenesis of adolescent idiopathic scoliosis in girls: a battle between two nervous systems, autonomic and somatic fought out in the spine and trunk - a theory [abstract]. In Proceedings of British Scoliosis Society Annual Meeting in conjunction with the British Scoliosis Research Foundation, J Bone Joint Surg $\mathrm{Br}$ Supp Institute of Child Health, London WCIN IEH; 2008 in press.

30. Burwell RG, Aujla RK, Grevitt MP, Dangerfield PH, Moulton A, Randell TL, Anderson SI: Pathogenesis of adolescent idiopathic scoliosis in girls. A double neuro-osseous theory involving disharmony between two nervous systems, somatic and autonomic expressed in the spine and trunk: possible dependency on sympathetic nervous system and hormones with implications for medical therapy. Scoliosis in press.

31. Harada Y, Takemitsu Y, Imai M: The role of contour line photography using the light cutting method and Moire photography in school screening for scoliosis. In Moire fringe topography and spinal deformity. Proceedings of an International Conference Edited by: Morealnd MS, Pope MH, Armstrong GWD. New York: Pergamon Press; 1981:||13-12|

32. Burwell RG, James NJ, Johnson F, Webb JK, Wilson YG: Standardised trunk asymmetry scores. A study of back contour in healthy school children. J Bone Joint Surg Br 1983, 65(4):452-63.

33. Burwell RG, Patterson JF, Webb JK, Wojcik AS: School screening for scoliosis - The multiple ATI system of back shape appraisal using the Scoliometer with observations on the sagittal declive angle. In Surface Topogaphy and Body Deformity, Proceedings of the 5th International Symposium, September 30-October I 1988 Wien Edited by: Neugebauer H, Windischbauer G. Stuttgart: Gustav Fischer; 1990: 17-23.

34. Burwell RG, Aujla RK, Kirby AS, Moulton A, Webb JK: The early detection of adolescent idiopathic scoliosis in three positions using the scoliometer and real-time ultrasound: should the prone position also be used? Stud Health Technol Inform 2002, 88:74-80.

35. Burwell RG, Aujla RK, Cole AA, Kirby AS, Pratt RK, Webb JK, Moulton $A$ : Back shape assessment in each of three positions in preoperative patients with adolescent idiopathic scoliosis: evaluation of a 10 -level Scoliometer method interpolated to 1 8-levels. Stud Health Technol Inform 2002, 9 I: I 19-22.

36. Grivas TB, Vasiliadis ES, Koufopoulos G, Segos D, Triantafyllopoulos $G$, Mouzakis V: Study of trunk asymmetry in normal children and adolescents. Scoliosis 2006, I: 19.

37. Natural History Committee of the British Scoliosis Society (Chairman R.G. Burwell): A multicentre study of back shape in schoolchildren. A progress report: positional changes in back contour in relation to a new screening test for scoliosis. In Surface Topogaphy and Spinal Deformity Proceedings of the 4th International Symposium September 27-30, 1986, Mont Sainte Marie, Quebec Edited by: Stokes IAF, Pekelsky JR, Moreland MS. Stuttgart:Gustav Fischer; 1987:|39-I5I.

38. Upadhyay SS, Burwell RG, Nicholson UJ, Webb JK: The Intgrated Shape Imaging System (ISIS) and the Scoliometer for recording back shape in scoliosis. A reliability and comparative study revealing positional changes in back contour (hump dynamics). In Surface Topogaphy and Spinal Deformity Proceedings of the 4th International Symposium September 27-30, 1986, Mont Sainte Marie, Quebec Edited by: Stokes IAF, Pekelsky JR, Moreland MS. Stuttgart:Gustav Fischer; 1987:233-248.

39. Upadhyay SS, Burwell RG, Webb JK: Hump changes on forward flexion of the lumbar spine in patients with idiopathic scoliosis. A study using ISIS and the Scoliometer in two standard positions. Spine 1988, I3(2):|46-5I.

40. Burwell RG: The British decision and subsequent events. Spine 1988, 13:11 92-4.

41. Grivas TB, Nakos B, Kouvaras J, Kalamakis N, Polyzois D: Study of the natural history of the back trunk shape by the Scoliome- ter in children aged 5- 12 years. Stud Health Technol Inform 1999, 59:223-6.

42. Grivas TB, Vasiliadis ES, Mihasc Maziotou C, Triandafyllopoulos G: Back trunk morphology in 330 I children aged 3-9 years old. Stud Health Technol Inform 2008, 140:29-32.

43. Scutt ND, Dangerfield PH, Dorgan JC: The relationship between surface and radiological deformity in adolescent idiopathic scoliosis: effect of change in body position. Eur Spine J 1996, 5(2):85-90.

44. Kouwenhoven JW, Castelein RM: The pathogenesis of adolescent idiopathic scoliosis. Review of the literature. Spine 2008, 33(26):2898-2908.

45. Grivas TB, Vasiliadis ES, Mihas C, Triantafyllopoulos G, Kaspiris A: Trunk asymmetry in juveniles. Scoliosis 2008, 3(I): 13 .

46. Grivas TB, Samelis P, Chadziargiropoulos T, Polyzois B: Study of the rib cage deformity in children with 10 degrees-20 degrees of Cobb angle late onset idiopathic scoliosis, using rib-vertebra angles - aetiologic implications. Stud Health Technol Inform 2002, 91:20-4.

47. Burwell RG, Aujla RK, Freeman B], Dangerfield PH, Cole AA, Kirby AS, Polak FJ, Pratt RK, Moulton A: The posterior skeletal thorax: rib-vertebral angle and axial vertebral rotation asymmetries in adolescent idiopathic scoliosis. Stud Health Technol Inform 2008, 140:263-8.

48. Grivas TB, Vasiliadis ES, Mihas C, Savvidou O: The effect of growth on the correlation between the spinal and rib cage deformity: implications on idiopathic scoliosis pathogenesis. Scoliosis 2007, I4(2): II.

49. Kiel AW, Burwell RG, Moulton A, Purdue M, Webb JK, Wojcik AS: Segmental patterns of sagittal spinal curvature in children screened for scoliosis: kyphotic angulation at the thoracolumbar region and the mortice joint. Clin Anat 1992, 8:353-37I.

50. Grivas TB, Dangas S, Samelis P, Maziotou C, Kandris K: Lateral spinal profile in school-screening referrals with and without late onset idiopathic scoliosis 10 degrees-20 degrees. Stud Health Technol Inform 2002, 91:25-3I.

51. Kirby AS, Burwell RG, Cole AA, Pratt RK, Webb JK, Moulton A: Evaluation of a new real-time ultrasound method for measuring segmental rotation of vertebrae and ribs in scoliosis. Stud Health Technol Inform 1999, 59:316-20.

52. Kouwenhoven JWM, Vincken KL, Bartels LW, Castelein RM: Analysis of pre-existent vertebral rotation in the normal spine. Spine 2006, 3I(I3): I467-I472

53. Kouwenhoven JW, Smit TH, Veen AJ van der, Kingma I, van Dieën JH, Castelein RM: Effects of dorsal versus ventral shear loads on the rotational stability of the thoracic spine: a biomechanical porcine and human cadaveric study. Spine 2007, 32(23):2545-50.

54. Burwell RG, Aujla RK, Cole AA, Kirby AS, Pratt RK, Webb JK, Moulton $A$ : Relation of rib deformity to vertebral deformity in the transverse plane at the curve apex in preoperative adolescent idiopathic scoliosis (AIS): an ultrasound, radiological and surface study of pathomechanisms. In International Research Society of Spinal Deformities Symposium 2004 Edited by: Sawatzky BJ. University of British Columbia; 2004:302-6.

55. Grivas TB, Vasiliadis E, Mihas C, Kaspiris A, Triandaffylopoulos G Burwell RG: Correlation between body mass index (BMI) and trunk asymmetry in children and adolescents $5-17$ years old [Abstract]. Oral presentation, 6th Hellenic Orthopaedic Research Meeting, Piraeus 28-30th November 2008

56. Pruijs JE, Hageman MA, Keessen W, Meer R Van der, Van Wieringen JC: Spinal rotation meter: development and comparison of a new device. Acta Orthop Belg 1995, 61 (2): 107-I2.

57. Burwell RG, Aujla RK, Cole AA, Dangerfield PH, Moulton A: Body frame size and pelvic width as a reference standard for weight? Possible biological significance and evolutionary origin [abstract]. Clin Anat 2009, 22(3):4I0.

58. Ebling FJP: The neuroendocrine timing of puberty. Reproduction 2005, I 29:675-683.

59. Kaplowitz PB: Link between body fat and the timing of puberty. Pediatrics 2008, 12 I (Suppl 3):S208-S2I7.

60. Plant TM: The role of KISS-I in the regulation of puberty in higher primates. Eur J Endocrinol 2006, I55(SuppI I):SII-SI6.

61. Kauffman AS, Clifton DK, Steiner RA: Emerging ideas about kisspeptin-GPR54 signaling in the neuroendocrine regulation of reproduction. Trends Neurosci 2007, 30(10):504-5I. 
62. Crown A, Clifton DK, Steiner RA: Neuropeptide signaling in the integration of metabolism and reproduction. Neuroendocrinology 2007, 86(3): 175-182.

63. Badman MK, Flier JS: The adipocyte as an active participant in energy balance and metabolism. Gastroenterology 2007, |32(6):2 |03-2 | I5.

64. Patel MS, Elefteriou F: The new field of neuroskeletal biology. Calcif Tissue Int. 2007, 80(5):337-347.

65. Iwaniec UT, Boghossian S, Lapke PD, Turner RT, Kalra SP: Central leptin gene therapy corrects skeletal abnormalities in leptindeficient ob/ob mice. Peptides 2007, 28(5):1012-9.

66. Gat-Yablonski $G$, Phillip $M$ : Leptin and regulation of linear growth. Curr Opin Clin Nutr Metab Care 2008, I I (3):393-8.

67. Maor G, Rochwerger M, Segev Y, Phillip M: Leptin acts as a growth factor on the chondrocytes of skeletal growth centers. J Bone Miner Res 2002, I 7(6): 1034-43.

68. Burwell RG, Dangerfield PH, Freeman B]: Etiologic theories of idiopathic scoliosis. Somatic nervous system and the NOTOM escalator concept as one component in the pathogenesis of adolescent idiopathic scoliosis. Stud Health Technol Inform 2008, 140:208-17.

69. Hung VW, Qin L, Cheung CS, Lam TP, Ng BK, Tse YK, Go X, Lee $\mathrm{KM}$, Cheng JC: Osteopenia: a new prognostic factor of curve progression in adolescent idiopathic scoliosis. J Bone Joint Surg Am 2005, 87-A:2709-2716.

70. Szalay EA, Bosch P, Schwend RM, Buggie B, Tandberg D, Sherman F: Adolescents with idiopathic scoliosis are not osteoporotic. Spine 2008, 33(7):802-6.

7I. Stokes IA: Hueter-Volkmann effect. In Etiology of Adolescent Idiopathic Scoliosis: Current Trends and Relevance to New Treatment Approaches, State of the Art Reviews: Spine Volume 14. Issue 2 Edited by: Burwell RG, Dangerfield PH, Lowe TG, Margulies JY. Philadelphia, Hanley \& Belfus Inc; 2000:349-57.

72. Stokes IA: Analysis and simulation of progressive adolescent scoliosis by biomechanical growth modulation. Eur Spine J 2007, 16:1621-8.

73. Stokes IA, Burwell RG, Dangerfield PH: Biomechanical spinal growth modulation and progressive adolescent scoliosis - a test of the 'vicious cycle' pathogenetic hypothesis: Summary of an electronic focus group debate of the IBSE. Scoliosis 2006, I:I6.

74. Moreau A, Wang DS, Forget S, Azeddine B, Angeloni D, Fraschini F, Labelle H, Poitras B, Rivard CH, Grimard G: Melatonin signaling dysfunction in adolescent idiopathic scoliosis. Spine 2004, 29(16): 1772-178|.

75. Azeddine B, Letellier K, Wang DS, Moldovan F, Moreau A: Molecular determinants of melatonin signaling dysfunction in adolescent idiopathic scoliosis. Clin Orthop Relat Res. 2007 462:45-52.

76. Sevastik JA: Dysfunction of the autonomic nerve system (ANS) in the aetiopathogenesis of adolescent idiopathic scoliosis. Stud Health Technol Inform 2002, 88:20-3.

77. Iliopoulos P, Korovessis P, Koureas G, Zacharatos S, Stergiou P: Asymmetric evolution of anterior chest wall blood supply in female adolescents with progressive right-convex thoracic idiopathic scoliosis. Eur Spine I 2007, 1 6:1 343-1346.

78. Korovessis P, Iliopoulos P, Koureas G, Zacharatos S, Stergiou P: Evolution of anterior chest wall blood supply in female adolescents with progressive right-convex thoracic idiopathic scoliosis. J Spinal Disord Tech 2007, 20(3):190-4.

79. Repko M, Horky D, Krbec M, Chaloupka R, Brichtova E, Lauschová I: The role of the autonomic nervous system in the etiology of idiopathic scoliosis: prospective electron microscopic and morphometric study. Childs Nerv Syst 2008, 24(6):731-4.

80. Moreau A, Franco A, Azeddine B, Rompré PH, Bagnall KM, Poitras B, Labelle H, Rivard CH, Grimard G, Ouellet J, Parent S: High circulating levels of osteopontin are associated with idiopathic scoliosis onset and spinal deformity [Abstract]. In Proceedings of British Scoliosis Society 33rd Annual Meeting 23rd-24th April in J Bone Joint Surg Br Supp/ The Curve, Rutland Street, Leicester, LEI ISB UK; 2009 in press.

81. Azeddine B, Franco A, Rompré PH, Roy-Gagnon M-H, Turgeon I, Boiro MS, Blain S, Boulanger H, Wang DS, Bagnall KM, Poitras B, Labelle HLL, Rivard C-H, Grimard G, Ouellet J, Parent S, Moreau A: High circulating levels of osteopontin is associated with idiopathic scoliosis onset and spinal deformity progression
[Abstract]. In Proceedings of Pediatric Orthopaedic Society of North America 25th Anniversary 2009 Annual Meeting Boston, Massachusetts, April 30-May 2 Boston Marriott Copley Place; 2009:128.

82. Somerville EW: Rotational lordosis: the development of a single curve. J Bone Joint Surg Br 1952, 34-B:421-7.

83. Roaf R: The basic anatomy of scoliosis. J Bone Joint Surg Br 1966 , 48-B:786-92.

84. Millner PA, Dickson RA: Idiopathic scoliosis: biomechanics and biology. Eur Spine J 1996, 5:362-73.

85. Guo X, Chau WW, Chan YL, Cheng JY: Relative anterior spinal overgrowth in adolescent idiopathic scoliosis. Results of disproportionate endochondral-membranous bone growth. Bone Joint Surg Br 2003, 85-B: | 026-3 |.

86. Guo X, Chau WW, Chan YL, Cheng JC, Burwell RG, Dangerfield PH: Relative anterior spinal overgrowth in adolescent idiopathic scoliosis - result of disproportionate endochondral-membranous bonegrowth? Summary of an electronic focus group debate of the IBSE. Eur Spine ] 2005, I 4:862-73.

87. Chu WC, Man GC, Lam WW, Yeung BH, Chau WW, Ng BK, Lam TP, Lee KM, Cheng JC: Morphological and functional electrophysiological evidence of relative spinal cord tethering in adolescent idiopathic scoliosis. Spine. 2008, 33(6):673-680.

88. Chu WCW, Lam WWM, Ng BKW, Lam T-p, Lee K-m, Guo X, Cheng JCY, Burwell RG, Dangerfield PH, Jaspan T: Relative shortening and functional tethering of spinal cord in adolescent scoliosis - Result of asynchronous neuro-osseous growth? Summary of an electronic focus group debate of the IBSE. Scoliosis 2008, 3:8.

89. Wang WJ, Yeung HY, Chu WC, Tang NL, Lee KM, Burwell RG, Cheng JC: Top theories for the etiopathogenesis of adolescent idiopathic scoliosis. J Pediatr Orthop in press.

90. Burwell RG, Freeman BJC, Dangerfield PH, Aujla RK, Cole AA, Kirby AS, Pratt RK, Webb JK, Moulton A: Left-right upper arm length asymmetry associated with apical vertebral rotation in subjects with thoracic scoliosis: anomaly of bilateral symmetry affecting vertebral, costal and upper arm physes? Stud Health Technol Inform 2006, I 23:66-7I.

91. Vital JM, Beguiristain JL, Algara C, Villas C, Lavignolle B, Grenier N, Sénégas J: The neurocentral vertebral cartilage: anatomy, physiology and physiopathology. Surg Radiol Anat 1989, I I (4):323-8.

92. Yamazaki A, Mason DE, Caro PA: Age of closure of the neurocentral cartilage in the thoracic spine. J Pediatr Orthop 1998, I 8: | 68-72.

93. Rajwani T, Hilang EM, Secretan C, Bhargava R, Lambert R, Moreau M, Mahood J, Raso VJ, Bagnall KM: The components of the magnetic resonance image of the neurocentral junction. Stud Health Technol Inform 2002, 91:235-40.

94. Huynh AM, Aubin CE, Rajwani T, Bagnall KM, Villemure I: Pedicle growth asymmetry as a cause of adolescent idiopathic scoliosis: a biomechanical study. Eur Spine J 2007, I 6(4):523-9.

95. Wemyss-Holden SA, Burwell RG, Webb JK: Segmental evaluation of the rotational (torsional) deformity in scoliosis: anatomical observations and surgical significance. J Bone Joint Surg $\mathrm{Br}$ I994, 76-B(Supp I):9.

96. Birchall D, Hughes D, Gregson B, Williamson B: Demonstration of vertebral and disc mechanical torsion in adolescent idiopathic scoliosis using three-dimensional MR imaging. Eur Spine J 2005, I 4(2): I 23- I 29.

97. Sevastik JA: Right convex thoracic female adolescent scoliosis in the light of the thoracospinal concept. Stud Health Technol Inform 2006, I 23:552-8.

98. Sevastik J, Burwell RG, Dangerfield PH: A new concept for the etiopathogenesis of the thoracospinal deformity of idiopathic scoliosis: summary of an electronic focus group debate of the IBSE. Eur Spine J 2003, I 2:440-50.

99. Normelli H, Sevastik J, Akrivos J: The length and ash weight of the ribs of normal and scoliotic persons. Spine 1985, I 0(6):590-2.

100. Giampietro P, Ghebranious N, Raggio CL, Ivacic L, Staubli J, McPherson E, Glurich I, Burmester J, Pauli RM, Jacobsen FS, Rasmusen KJ, Faciszewski T, Boachie-Adjei O, Blank RD: Rib length discrepancy in adolescent with idiopathic scoliosis. Scoliosis Research Society 43rd Annual Meeting and Course, Salt Lake City, Utah, USA, September 10-13 $2008: 273$ 
101. Schwender JD, Denis F: Coronal plane imbalance in adolescent idiopathic scoliosis with left lumbar curves exceeding $40^{\circ}$. Spine 2000, 25(I 8):2358-63.

102. Burwell RG, Aujla RK, Freeman BJC, Dangerfield PH, Cole AA, Kirby AS, Pratt RK, Webb JK, Moulton A: Patterns of extra-spinal leftright skeletal asymmetries in adolescent girls with lower spine scoliosis: relative lengthening of the ilium on the curve concavity and of right lower limb segments. Stud Health Technol Inform 2006, I 23:57-65.

103. Burwell RG, Aujla RK, Grevitt MP, Dangerfield PH, Cole AA, Kirby AS, Polak FJ, Pratt RK, Webb JK, Moulton A, Anderson SI: Leptin, asymmetric bone growth, pathogenesis of adolescent idiopathic scoliosis (AIS) and hormesis: lower spine scoliosis [abstract]. Clin Anat 2009, 22(3):4II.

104. Calabrese E): Hormesis and medicine. Br J Clin Pharmacol 2008 , 66(5):594-617.

105. Haynes WG, Morgan DA, Walsh SA, Mark AL, Sivitz WI: Receptormediated regional sympathetic nerve activation by leptin. J Clin Invest 1997, $100(2): 270-8$.

106. Acampa M, Guideri F, Hayek J, Blardi P, De Lalla A, Zappella M, Auteri A: Sympathetic overactivity and plasma leptin levels in Rett syndrome. Neurosci Lett 2008, 432(I):69-72.

107. Nomura Y, Kimura K, Arai H, Segawa M: Involvement of the autonomic nervous system in the pathophysiology of Rett syndrome. Eur Child Adolesc Psychiatry 1997, 6(Suppl I):42-6.

Publish with Bio Med Central and every scientist can read your work free of charge

"BioMed Central will be the most significant development for disseminating the results of biomedical research in our lifetime. "

Sir Paul Nurse, Cancer Research UK

Your research papers will be:

- available free of charge to the entire biomedical community

- peer reviewed and published immediately upon acceptance

- cited in PubMed and archived on PubMed Central

- yours - you keep the copyright 